\title{
Conceptualizing Security Governance
}

\author{
ELKE KRAHMANN
}

\begin{abstract}
This article examines the changing transatlantic security architecture since the end of the Cold War. It argues that the absence of a unifying military threat and the subsequent broadening of the notion of security from states to societies has led to the increasing differentiation of security policy arrangements since the beginning of the 1990s. Not only have international institutions proliferated since the end of bipolarity, private actors - such as non-governmental organizations and private security companies - have gained considerable influence. Since these features are not fully grasped by traditional models in security studies, the article suggests that a new theoretical perspective might be required if we are to understand the emerging security system. It proposes that such a perspective can be based on the concept of 'security governance', which describes the development from the centralized security system of the Cold War era to the increasingly fragmented and complex security structures of today.
\end{abstract}

Keywords: end of bipolarity; governance; privatization; security

Since the end of the Cold War, fundamental changes have transformed the transatlantic security architecture. Not only has the region witnessed the dissolution of the bipolar structure which centred around the Atlantic Alliance on the one hand and the Warsaw Pact on the other, it has also seen the emergence of a large number of new bilateral and multilateral security institutions. However, the complexities of this new security environment are not fully grasped by the concept of multipolarity. Although the new structure appears to have several centres, these centres no longer seem to be states, but regional and subregional institutions through which an increasing range of public and private actors organize their common or competing interests in international security. The membership of and relations among these institutions are varied and overlapping, and so are their functions and obligations.

In response to these observations, this article proposes and illustrates the utility of a new theoretical framework for the analysis of the evolving transatlantic security architecture, which complements traditional models of security relations such as alliances, security regimes and security communities. It suggests that part of the transformation of transatlantic security policy from its state-centred bias and two central multilateral organizations towards complex networks of state and non-state actors can be understood

Cooperation and Conflict: Journal of the Nordic International Studies Association Vol. 38(1): 5-26. Copyright @2003 NISA www.ps.au.dk/NISA

Sage Publications www.sagepublications.com 0010-8367[200303]38:1;5-26;031297 
in terms of an emerging shift from 'government' to 'governance'. The changes in transatlantic security policy-making, thereby, appear to follow a trend which has been observed in subnational, national and regional policy since the 1980s (Pierre, 2000b). Characteristic of this development is the fragmentation of political authority among a diversity of public and private actors across levels of analysis.

The consequences of this shift towards a system of 'security governance' in the post-Cold War era for the analysis of security are manifold. Specifically, this article points to a differentiation in the making and implementation of security policies. It does not question that states retain a central role in international security. However, governments seem increasingly willing to rely on the cooperation and resources of non-state actors, such as private security companies, non-governmental organizations (NGOs) and international organizations (Lilly, 2000; Rosenau, 2000; Cooley and Ron, 2002; Mandel, 2002). The proposed framework aims to analyse the nature and dimension of these changes in Europe and North America. Moreover, it suggests that the trend from government to governance might determine the future evolution of transatlantic security. By providing a framework for the comparison with governance arrangements in other sectors, this article seeks to help to analyse this evolution and the problems which might be associated with it. Specifically, it points out that features and problems of governance which have been noted in other sectors, such as a loss of public accountability and a lack of coordination among public and private actors, already appear to be affecting the emerging system of security governance in Europe and North America.

In the following, this article is structured in three parts. The first part discusses the ability of traditional security theories to model the changing transatlantic security architecture. The second part develops the concept of security governance and proposes a framework for its analysis based on the comparative analysis of governance at the subnational, national and international levels. The third part examines how this framework can help us understand the transformation of transatlantic security policy-making since the end of the Cold War, and the conclusion discusses the new insights which might be gained from the application of the proposed framework and the questions it raises for the future of European and North American security policy-making.

\section{Theory and the Changing Transatlantic Security Architecture}

Three main central theoretical approaches can be distinguished in the analysis of security: balance-of-power theory, security regimes and security communities. All of these models have, with varying success, been employed to explain the transformations of the transatlantic security architecture after the end of the Cold War.

In particular, balance-of-power has been put into question not only by empirical observations, but also by scholarly disagreements about the propositions of the model and the structure of the current international 
system (Wohlforth, 1999: 6). Originally, balance-of-power theory led scholars to expect that the end of bipolarity and the absence of a single unifying threat in the form of the Soviet Union would lead to new isolationism in the US, the dissolution of NATO and the re-emergence of balancing behaviour in Europe (Mearsheimer, 1990a, b; Waltz, 1993). However, the actual transformation of the transatlantic security architecture in the 1990s quickly challenged these expectations. In spite of what has been termed 'incipient' multipolarity, NATO not only survives, but also continues to expand its functional and geographical scope. Moreover, rather than reverting to competitive balancing behaviour, governments in Europe and North America have strengthened their bilateral and multilateral relations in security through new institutional arrangements, such as the 'Partnership for Peace' and the Euro-Atlantic Cooperation Council. Although these new security arrangements are more flexible than during the Cold War, military conflict among NATO's expanding range of members seems as unlikely as among the old allies.

The alternative contentions that the current international system is not multipolar, but is characterized by a 'unipolar moment' (Layne, 1993) or by regions of 'benign unipolarity' (Kupchan, 1998), are equally contestable. Notably, the explanation that unipolarity 'provides order and stability through power asymmetry and the structural hierarchy that follows from it' (Kupchan, 1998: 45) requires the introduction of auxiliary premises which not merely go beyond traditional balance-of-power theory, but in fact seem to contradict the model's basic presumptions (Kupchan, 1998: 50-2). Essentially these auxiliary premises, such as the relevance of norms and institutions, match those advanced by the notion of security regimes which can be conceived of as the second key approach to international security.

Security regimes are defined as 'sets of implicit or explicit principles, norms, rules, and decision-making procedures around which actors' expectations converge' (Krasner, 1983: 2) in the area of security. In a multipolar system, security regimes foster stability because states value peace and cooperation, refrain from expansion and view the unilateral pursuit of peace as too costly (Jervis, 1982: 360-2). Even if the international environment changes, as with the end of the Cold War, security regimes survive because of opposition to changes of the status quo, the norm of reciprocity and the institutionalization of these regimes (Jervis, 1982: 366 f.). In addition, regimes are typically supported by influential hegemons who helped to create them (Jervis, 1982: 360; Snyder, 1996: 566).

The developments in the transatlantic security architecture since the 1990s appear to support the security regime approach. In particular, the model explains why NATO, which has been considered as the first security regime to emerge in the region after the end of the Second World War, has not been dismantled. Not only has the institutionalization of NATO ensured that both officials and politicians had a vested interest in its continuation, the US as NATO's hegemon has so far also played a crucial role in its survival by promoting the extension of NATO's functions and membership. 
However, similar explanatory capabilities might be ascribed to the concept of security communities, which shares many of the basic assumptions of the security regime. A pluralistic security community is defined as a 'region of states whose people maintain dependable expectations of peaceful change' (Adler and Barnett, 1998: 30). According to Adler and Barnett, security communities are facilitated by three factors which build upon another: (1) precipitating conditions, such as changes in technology, demography, economics, the new interpretation of social relations and external threats, (2) factors conducive to mutual trust and the development of a collective identity, such as transactions, organizations and social learning, and (3) necessary conditions, such as mutual trust and a collective identity (Adler and Barnett, 1998: 38). Like security regimes, security communities benefit from a powerful state's 'ability to nudge and occasionally coerce others to maintain a collective stance' (Adler and Barnett, 1998: 39). The main difference between the two approaches lies in the role that the security community model attributes to a collective identity in fostering peace and stability (Adler and Barnett, 1998: 47).

Applied to the changes in the transatlantic security system after the end of the Cold War, the concept suggests that the region did not revert to competitive balancing behaviour because it has developed a common identity since the end of the Second World War. Moreover, the security community approach illustrates why Central and East European countries that share many cultural, historical and political characteristics with the West may wish to join the Atlantic Alliance and the European Union (Adler and Barnett, 1998: 40).

However, while both latter approaches explain the main aspects of the transformation of transatlantic security, they do not address the increasing internal differentiation and fragmentation of the post-Cold War security architecture. In particular, four developments can be noted which are changing the ways in which security policies are made and implemented in the region.

First, since the end of the Cold War a broad range of new institutions have been created to address the specific security needs of a limited number of countries, rather than the transatlantic community as a whole. Most of these formal and informal relations, such as the Baltic Cooperation Council or the Visegrad Nine, share the foundations of security regimes and communities in that they are based on values of peace and collaboration, nonexpansive behaviour and the wish to reduce the cost of security. They also typically build on a shared culture and identity. However, although these institutions do not appear to undermine the basic cohesion of the transatlantic security community, they increasingly allow varying sets of governments to pursue different national and international security policies.

Second, many of these new arrangements which deal with localized or non-traditional security issues are more fluid and flexible than security regimes or communities. They often emerge from the unique interests and resources of a set of actors in solving a particular security problem, such as armaments research and development, military training or surveillance. The 1990s have thus witnessed the unprecedented proliferation of bilateral or 
multilateral security collaboration, including the Danish-German-Polish trilateral cooperation, the joint Baltic peace-keeping battalion BALTBAT, the common Baltic air surveillance system BALTNET and the Belgian-Dutch deployable air force, to name but a few. ${ }^{1}$

Third, although security regimes, such as NATO and the emergent Common European Security and Defence Policy (CESDP), are key agents in transatlantic security, these organizations increasingly favour the implementation of security policies by changing coalitions of member states rather than the collective institution. In particular, NATO's new concept of Combined Joint Task Forces (CJTF) has been designed to encourage ad hoc cooperation among a limited number of states in international missions. Similarly, the CESDP of the EU envisages that future international operations will be conducted by 'coalitions of the willing'.

Finally, there seems to be a growing involvement and reliance on private actors in transatlantic security. In addition to the privatization of the armaments industry and the proliferation of private security companies which offer a whole range of security services to governments and international organizations in the region, governments are progressively turning to the resources and expertise of non-governmental organizations to deal more efficiently with a variety of military and non-military threats (Kassebaum, 2000; Cooley and Ron, 2002; Mandel, 2002). Moreover, private security actors at different levels are independently addressing issues such as civil war, transnational crime and non-proliferation (Bøås, 2000: 312 f.). Although the influence of these actors is not comparable with that of governments or international organizations, their growing role in the management of transatlantic security is recognized by the latter and efforts to enhance civil-military cooperation have been called for within NATO and other institutions (NATO, 2000; CSCE, 1992).

While none of these changes appear to challenge the existing transatlantic security regimes and community, they nevertheless point to an underlying rearrangement of the transatlantic security architecture. Notably, these transformations are affecting the way in which security is defined in Europe and North America, by whom security policies are made and how they are implemented. The following section develops the notion of 'security governance' to provide a theoretical framework for analysing these changes and to indicate how the concept of governance might be used to understand this evolution and the problems which might arise from it.

\section{From Government to Governance in International Security}

In order to arrive at an understanding of security governance, it is first necessary to specify what is meant by its two component terms: security and governance. The meaning of security has been widely contested since the 1980s (Ullman, 1983; Walt, 1991; Rothschild, 1995; Baldwin, 1997). At the heart of the debate there have been attempts to deepen and widen the concept of security from the level of the state to societies and individuals, and from military to non-military issues. 
This challenge to a state-centric notion of security builds upon the argument that the end of the Cold War has significantly reduced the likelihood of interstate war, whereas the threat from civil war, transnational crime, terrorism and infectious diseases appears to have increased. In 1999, about 32,000 individuals were killed in interstate wars. However, more than 900 people were killed through terrorist attacks, up to 39,000 were killed in civil conflicts and no less than 2.8 million were killed by AIDS (UNAIDS, 2000). The changing balance becomes even more striking in the data provided by the Swedish Peace Research Institute SIPRI, which recorded on average 27 major conflicts per year between 1990 and 2000, but only 8 interstate wars during the entire 10 -year period.

While academics have remained divided over the utility of a more inclusive notion of security (Krause and Williams, 1997), politicians, the military and the security industry quickly picked up on these new security threats after the end of the Cold War. NATO and the Conference for Security and Cooperation in Europe (CSCE), for instance, have successfully found a new role by expanding the scope of their security functions to areas such as the war on terrorism, international peace-keeping, refugee resettlement and the promotion of civil society. Even the European Union and its member states are defining an increasing array of their concerns in terms of security, including immigration and development aid (Manners, 2002). Although some scholars have criticized the 'securitization' of political, social or environmental issues (Wæver, 1995), this article suggests that a broad notion of security has come to define much of the practice of contemporary security policy-making and it is therefore used throughout this study.

At the same time as governments and international organizations have expanded their security functions, however, limited resources, lack of expertise in non-traditional areas of security and divergent interests among the governments of Europe and North America have facilitated the increasing fragmentation of authority in security policy-making. In addition to national governments and international organizations, a variety of private actors, ranging from charities to private security companies, have emerged in local, regional and global security, dealing with issues such as humanitarian aid (OXFAM, 2000; CARE, 2001), human rights monitoring (Amnesty International, 2002; Human Rights Watch, 2002), refugees (ICRC, 2001; International Rescue Committee, 2002) and military training and protection (MPRI, 2002).

While in the area of security the relations between diverse groups of actors have traditionally been conceived in terms of alliances or communities, the fragmented but overlapping networks which structure the collaboration among the growing range of public and private security actors seem to be more adequately described by the concept of governance. Although the concept of governance is sometimes defined as a generic term which includes 'any form of coordination of interdependent social relations' (Jessop, 1999: 351) ranging from centralized state control to self-regulation (Rhodes, 1996: 653; Eising and Kohler-Koch, 1999: 5; Pagoulatos, 1999: 68), the notion that government can be differentiated from governance appears to be more fruitful (Krahmann, forthcoming). In this tradition, government 
refers to the political control of a centralized state, whereas governance denotes the coordination of social relations in the absence of a unifying authority at the subnational, national or international levels (Czempiel, 1992: 250; Gordenker and Weiss, 1996: 17). A more restrictive definition of the term governance might thus be suggested as follows:

Governance denotes the structures and processes which enable a set of public and private actors to coordinate their interdependent needs and interests through the making and implementation of binding policy decisions in the absence of a central political authority.

Two arguments support such a restrictive definition of governance. First, various types of policy-making arrangements have always existed and would not necessitate the introduction of governance as an overarching term. Indeed, it is difficult to say how the definition of governance as a generic category can be distinguished from the meaning of politics itself. Second, contrary to the observation that governing can take a variety of forms, the fragmentation of political authority among public and private as well as subnational, national, regional and international actors has been a relatively recent development in the 1980s and 1990s (Rhodes, 1996: 661; Jessop, 1999: 355). In the domestic arena, it has been characterized by the outsourcing of central government functions to the private sectors, the introduction of market mechanisms and self-government at the local or sectoral level (Stewart and Stoker, 1995; Butcher, 1995; Majone, 1997). In the international arena, it has been revealed by the increased willingness of national governments to engage in multilateral cooperation in order to achieve common objectives (UN Charter, 1945; Treaty of the European Union, 1997).

It is this delegation of authority and the outsourcing of public policy functions that transatlantic governments had accumulated over the past decades which requires a new term. This does not, however, imply that fragmented modes of governing are an entirely new phenomenon. It rather suggests a lack of appropriate theoretical concepts. Analyses of governance at the domestic level have coined the term 'new medievalism' to suggest the similarities of current policy-making arrangements with the dispersion of political authority in the middle ages (Payne, 2000: 206). Moreover, centralized authority and the delivery of public services, such as health and transport, by the state has been mainly a European prerogative. A similar argument can be made concerning the centralized provision of security, which seems to have been the exception, rather than the rule, in geographical as well as historical terms.

Several factors have been identified by the literature as driving the shift from government to governance at the national, regional and international levels. The first factor is increasing budgetary pressures which have encouraged the outsourcing and privatization of public policy functions in a bid for improved efficiency (Majone, 1997: 139, 142). The second factor is a growing awareness of global problems and new security threats, such as transnational crime, terrorism and migration, which can only be resolved through international cooperation (Rosenau, 1992: 3; Tuathail et al., 1998: 
12). The third factor is globalization, specifically increased transnational contact, which is creating or exacerbating many of these problems (Gordenker and Weiss, 1996: 20; Zangl and Zürn, 1999: 140).

The literature further suggests that governance can be differentiated from government along seven dimensions: (1) geographical scope, (2) functional scope, (3) distribution of resources, (4) interests, (5) norms, (6) decision-making and (7) policy implementation. Each dimension can take a variety of forms along a scale between the ideal notion of government, i.e. centralization and integration, and governance, i.e. fragmentation and differentiation. However, it should be noted that not all dimensions apply to every issue area. For instance, some governance structures might not be defined by a geographical dimension, but purely in functional terms, such as the Convention on the Law of the Sea. With the help of these seven dimensions a framework for the analysis of policy-making arrangements can be established which distinguishes between government and governance as ideal-typical poles. In order to delineate this framework, the following briefly describes the scope of each dimension.

According to the ideal-type distinction between government and governance, geographical centralization is defined as policy-making arrangements which are based on the state as the key unit. As a consequence, fragmentation can take three forms: 'downwards' to local or regional entities, 'upwards' to the macro-regional or global level or 'sideways' to private and voluntary actors (Rhodes, 1999: xxiii). Crucially for this interpretation, the noted 'upward' shift does not represent a substitution of the state as central authority by international institutions, which would suggest centralization at a new level, but typically marks the dispersion of political authority between governments and their international organizations.

Functionally, policy-making takes a centralized form if different sectors or issue areas are integrated through a comprehensive system that is coordinated by a single authority (Rose, 1980: 16; Stewart and Stoker, 1995: 196). Conversely, a fragmented governance arrangement would be characterized by the regulation of different issue areas by multiple and separate authorities, including public or private actors (Majone, 1997: 154).

The distribution of resources can also be understood in terms of centralization and fragmentation. In centralized arrangements, all or most resources that are required for the making and implementation of policies are ideal-typically held or channelled by the government. Conversely, in fragmented governance arrangements, resources are dispersed among a range of public and private actors who have to coordinate their efforts in order to resolve common problems (Walsh, 1995: 43; Rhodes, 1999: xviii; Pierre, 2000b: 242).

With regard to interests, the distinction between centralization and differentiation is more complex. Even central governments have to accommodate a range of diverse interests from societal and state actors. Nevertheless, it can be argued that the underlying premise of central government is that individual preferences can and should be subordinated to the common interest (Rose, 1980: 23 f.; Pierre, 2000a: 2; Jessop, 2000: 13). Conversely, governance accepts the heterogeneous and sometimes conflicting 
nature of interests and seeks to ensure that each actor can pursue them uninhibited by external regulation. In so far as coordination is necessary, it is perceived to be best left to market forces or the actors themselves. The seeming contradiction that consensus appears to be more common in governance than government arrangements (Pierre, 2000b: 245; Jessop, 2000: 17) can be explained by the observation that governance encourages self-government among the small, relatively homogeneous sets of actors who are immediately affected by an issue. Governance arrangements are, therefore, more likely to bring together like-minded actors than arrangements which centralize decision-making from different regions and sectors.

In its ideal-type interpretation, the interest dimension is closely linked to the norms which underlie government and governance, respectively. Norms can be defined in terms of centralization or fragmentation in that they either promote a strong state or prioritize the right to self-determination among public and private actors. Three norms have supported the central authority of the state vis-à-vis national and international actors: sovereignty, command and control, and the ideal of redistribution (Majone, 1997; Jessop, 1999: 354). The opposing principle of differentiation is represented in the increasing limitation of national sovereignty, self-government and the marketization of social relations (Walsh, 1995: 28; Jessop, 1999: 354; Rhodes, 1999: xvii).

Finally, the division between centralization and fragmentation applies to the structures and processes of decision-making and implementation. Decision-making processes which are centralized around government agencies are characterized by their hierarchical, democratic and consensual nature (Majone, 1997: 162; Jessop, 2000: 13). The highest decision-making authority rests with national governments. Subnational or international decision-making bodies are subordinate to them. Within governments, decisions are taken according to the democratic principles of qualified or absolute majority voting. In international organizations, decision-making is based on a consensus among member governments. Governance, on the contrary, is defined by the horizontal dispersion of authority among public and private actors at different levels. Decision-making proceeds through negotiation and the formal and informal acceptance of structural inequality, for instance through weighted voting procedures (Rhodes, 1999: xxi; Jessop, 2000: 15 f.).

Policy implementation through government is centralized, authoritative and, if necessary, coercive (Aquina and Bekke, 1993: 160; Stoker, 2000: 3; Pierre, 2000a: 2). Within governance arrangements, policies are implemented in a decentralized fashion. Typically, policies are self-enforced and compliance is voluntary (Walsh, 1995: 35; Majone, 1997: 146; Rhodes, 1999: xvii; Pierre, 2000b: 242).

\section{The Rise of Security Governance}

Obviously, it is difficult to specify which or how many dimensions have to be fragmented for a policy-making structure to qualify as 'governance' 
rather than 'government'. ${ }^{2}$ Moreover, the formal and informal institutions on which these political structures are based are constantly evolving. Separate dimensions may proceed towards greater fragmentation or integration. In fact, different dimensions might display countervailing trends. Nevertheless, it can be argued that in security a clear trend from government to governance can be noted since the end of the Cold War. Taking each dimension in turn, the following points out some general observations suggesting that a new system of security governance might be emerging in Europe and North America.

\section{Geographical Dimension}

The geographical transformation of the post-Cold War security architecture is usually interpreted as characterized by increasing integration due to the expansion of NATO and the European Union. In terms of the framework proposed in this article, however, it suggests a movement from government to governance, since it indicates the dispersion of authority between different sets of governments and international organizations. Moreover, it should be pointed out that the enlargement processes of NATO and the EU have not reduced the geographical fragmentation and complexity of the current transatlantic security architecture, but merely shifted its borders. In fact, it can be argued that the enlargement process has contributed to the creation of a variety of new geographical arrangements that differentiate between new, soon-to-be, would-be and not-to-be members.

Specifically, several developments can be observed which have led to a greater geographical diversity of security governance arrangements since the end of the Cold War. First and foremost, there has been a rearrangement of security institutions at the international level due to the dissolution of the Warsaw Pact and the Soviet Union, which, until the early 1990s, centralized security policy-making in Eastern Europe. Although Russia and the newly independent states in Central and Eastern Europe quickly became members of the UN and OSCE, none of the Soviet successor states, have so far considered membership in NATO as the main security organization in the transatlantic region. In the place of a formal and swift integration of Eastern Europe into Western security arrangements or the development of a new comprehensive structure under the auspices of the OSCE, a network of multilateral agreements has evolved which institutionalizes the geographical differentiation of security governance in the transatlantic region. In particular, NATO's Partnership for Peace (PfP) programme consists of a series of bilateral arrangements between NATO and individual states in Central and Eastern Europe which specify cooperation in areas such as defence-related cooperation, crisis management, civil emergency planning, air traffic management or armaments production. In addition, NATO has signed two treaties with Russia and Ukraine. ${ }^{3}$ There is also a growing number of bilateral cooperation agreements between Western industrialized countries and East European states as well as among Western states themselves, notably for enhancing the interoperability of 
armed forces and armaments production. ${ }^{4} \mathrm{Bi}$ - and trilateral agreements are complemented by increasing regional and subregional differentiation, such as the Council of the Baltic Sea States, the Stability Pact of South-Eastern Europe or the Visegrad Group (Cottey, 2000).

In addition to the fragmentation of security policy arrangements at the international level there has been a progressive 'sideways' shift towards private security actors. This shift includes not only the privatization and internationalization of the armaments industry in Europe and North America (Sköns and Wulf, 1994), but also the emergence of private transnational security companies which offer security services, such as training and logistics, to governments, NGOs and international organizations in the region and beyond (Arnold, 1999: 173; Brooks, 2000: 137; Singer, 2001: 14).

\section{Functional Dimension}

As in the case of the geography of post-Cold War security governance, the functional dimension initially seems to indicate greater centralization. Thus, it can be argued that, due to the broadening of the concept of security from military to human security issues, the scope of the functions and institutions associated with security policy has been enlarged. However, several developments that promote governance rather than government can be linked to the broadening of the definition of security. In particular, the introduction of the notion of human security has failed to lead to the formation of a unified organizational structure or policy that helps to coordinate the provision of security across multiple sectors. Instead, the institutional divisions within and between organizations engaged in the making and implementation of security policies at different levels and in diverse issue areas have broadly been maintained.

Indeed it can be argued that, with the exception of the European Union's emerging Common European Security and Defence Policy, the functional expansion of national and international organizations after the end of the Cold War has been limited. After an initial phase during the early 1990s, when many international organizations embraced more comprehensive definitions of security, ${ }^{5}$ the governance of transatlantic security has consolidated around traditional divisions of responsibility. The preservation of state borders has remained the key function of national armies and NATO; ${ }^{6}$ human rights continue to be primarily a concern for the Council of Europe, the OSCE and the UN, as well as non-governmental organizations such as Amnesty International $;^{7}$ and non-traditional issues such as global health, development and environmental security rely on a broad range of public and private actors, including the $\mathrm{UN}$ and the European Union for their provision (Young, 1997; Clapp, 1998; Jordan, 1999). In fact, the growing recognition of non-traditional areas of security combined with the limited expertise and resources of governments in these areas has strengthened the role of private actors in the governance of security and thus the trend towards functional specialization. 


\section{Distribution of Resources}

The increasing fragmentation and differentiation of security resources and capabilities has perhaps been the most pronounced aspect of the trend towards a system of security governance in the region. In the immediate aftermath of the Cold War, it was driven by public demands for cutbacks in national defence spending (Croft and Dunn, 1990; Carver, 1992: 155). In addition, governmental resources have become more and more limited because of the rising costs of standing armies, professional training and armaments research and development (Greenwood, 1991; Smith, 1993). As governments in Europe and North America have been induced to seek more cost-effective ways for the provision of national security, they have increasingly relied on the resources of private actors. In non-traditional areas of security, where the involvement of non-governmental actors has been strong, charities, environmental organizations and human rights watchdogs have become central agents in the making, implementation and monitoring of security policies. However, also in the areas of traditional defence policy, governments collaborate with private actors in the provision of security. In particular, the privatization of armaments industries in Western Europe during the 1990s (Bitzinger, 1994; Sköns and Wulf, 1994; Guay, 1998) and the professionalization of the armed forces are parts of a progressive shift from national autonomy in security affairs to new forms of public-private partnerships. ${ }^{8}$ Governments, international organizations and non-governmental organizations are also finding it progressively more efficient to hire private security companies for international operations rather than attempting to muster the relevant resources and expertise themselves (Adams, 1999; Spearin, 2001).

In addition to the diffusion of resources between public and private actors, governments and international organizations have recognized the need to share their capabilities. The complex arrangements for the use of national and multinational capabilities by NATO and the emerging Common European Security and Defence Policy are illustrative of this point. ${ }^{9}$ Less controversial, but equally relevant, have been the decisions by NATO and the WEU to offer their military structures for OSCE and UN missions. ${ }^{10}$ While these arrangements prevent duplication and allow the accumulation of specialist expertise and capabilities, they contribute to the fragmentation of security governance in the region.

\section{Interest Dimension}

In June 1990, the end of the Cold War appeared to have closed an era of conflicting interests and ideologies. ${ }^{11}$ Governments in the West and East began to identify common threats and problems and areas for prospective cooperation. However, the potential of this centralizing trend has been undermined by a number of factors. Although cooperation between the two former blocs has progressed significantly over the past decade, differences of interest in major areas of security continue to persist. The controversy between NATO and Russia over the enlargement of the Atlantic Alliance 
and the future security architecture of the region has been at the heart of the dispute. ${ }^{12}$ It has replaced the initial hope of the former Soviet President Gorbachev for a centralized security structure under the umbrella of the CSCE (Hurlburt, 1995; Sharp, 1995). Moreover, the integration of security interests by NATO's expansion is offset by the differentiated bilateral arrangements with its prospective members under the PfP programme. Thus, PfP takes the specific interests of the signatory governments into account and limits common obligations between the partners and the NATO member states..$^{13}$ In addition, there is an increased recognition and emphasis of the diverse, though not necessarily conflicting, security interests of governments in Europe and North America. The development of an independent Common European Security and Defence Policy is a first step towards enabling the European Union to pursue its own, more narrow, security concerns. However, even the new structures of the CESDP acknowledge the differentiated interests of the member states. Specifically, actions under the CESDP are based on varied 'coalitions of the willing. ${ }^{14}$ NATO has progressed towards a similarly flexible structure with the development of the Combined Joint Task Forces (Bensahel, 1999). Characteristic of these developments is that limited centralization is only achieved in the provision of core interests such as national defence, while regional, global and non-traditional security interests are defended by an increasing number of agents and institutions.

\section{Normative Dimension}

The trends towards a fragmentation of security governance described above are closely linked to underlying changes in the norms of government at the national and international level. The most radical change concerns the norm of state sovereignty in security which is progressively put into question. It culminated in the example of NATO intervening in Kosovo without the authorization of the UN Security Council. ${ }^{15}$ The move towards the limitation of national sovereignty has also been reflected by the willingness of governments to overrule the veto of one or two members involved in conflict within the OSCE..$^{16}$

A second development which can be associated with the evolution from government to governance is the weakening of the norm of collective responsibility. Although NATO has been the only international organization whose members subscribed to this norm and continue to do so, it can thus be noted that the ties that bind the members of NATO appear to be put into question by policies such as the American National Missile Defence programme and the preference given to coalitions of the willing by CJTF. Notably, in the only instance in which NATO's Article 5 has been invoked, namely following the September 11 terrorist attack on the United States, the US government decided not to rely on the Alliance.

Most fundamental, however, has been the abolition of a security policy based on ideological principles which justified the damaging economic burdens that contributed to the dissolution of the Soviet Union and placed significant costs on national governments during the Cold War. In its place, 
North American and European governments have embraced the notion of a cost-efficient security policy. In the area of national defence, the aim to reduce governmental spending has been exemplified by the wholesale of national armaments industries and sub-contracting of parts of the armed services; in subnational security, it has taken the form of private policing, and in issues of international security it has led to the enrolment of private actors, such as charities or private security companies, for the provision of humanitarian relief or the training of soldiers and peace-keepers (Brooks, 2000).

\section{Decision-Making}

Crucially for the analysis of security in the post-Cold War era, the differentiation of actors, functions and capabilities noted above has been accompanied by a fragmentation of the decision-making process. This trend towards governance takes two forms. First, security policy-making in contemporary Europe and North America is increasingly characterized by relatively closed issue networks in which decisions are taken through horizontal coordination and negotiation (Hueglin, 1999: 261; Rhodes, 1999: xxii; Eising and Kohler-Koch, 1999). At the national level, the formation of issuespecific networks among public and private actors has been associated with the overload of central governments (Self, 1980: 45; Mayntz, 1993: 10; Jessop, 2000: 14). At the international level, fragmented governance arrangements, such as regimes or transnational networks, have developed with the progressive institutionalization of decision-making among selective groups of states or public and private actors with common concerns due to the absence of a central authority (Senghaas, 1993: 248; Mittelman: 1996: 189; Gordenker and Weiss, 1996: 17).

Second, security policy decision-making within multilateral institutions is increasingly moving away from the doctrine of consensus, based on the formal equality and sovereignty of governments, in favour of weighted voting or consensus minus one procedures. Both developments can be interpreted as a trend towards governance in that 'governance' unlike 'government' in the liberal democratic tradition does not attempt to compensate for the inherent differences of power among the various actors engaged in the political process. Thus, the European Union is in the process of reforming its decision-making system by a re-consideration of the votes attached to each member state. This reform will end the Union's tradition of granting disproportionately greater influence to the smaller member states in order to safeguard their interests. ${ }^{17}$ Similar challenges to consensual decisionmaking are faced by NATO following the Prague round of enlargement. The OSCE has already embraced this step towards governance by its decision in 1992 to permit its members in effect to overrule a veto in order to allow action against one or two members engaged in conflict. ${ }^{18}$

\section{Policy Implementation}

The development towards governance has progressed even further with 
regard to the implementation of security policies in the transatlantic community. Governments and international organizations increasingly draw on the resources of non-governmental actors at different levels. The implementation of security policies is therefore becoming more and more fragmented: geographically, functionally and in terms of the division between public and private providers (Tuathail et al., 1998: 14; Commission on Global Governance, 1995: 2 f.; Rosenau, 2000: 172 f.). Some members of the European Union and NATO, for instance, envisage a distribution of labour in which the Union focuses on the implementation of security policies in Europe while NATO serves as a global agent. Lord Robertson's offer that NATO's military headquarters could provide the planning for Turkey if it would take over the command of the international peace-keeping operation in Afghanistan suggests another division of security functions in which NATO might increasingly take on a management and coordination role. ${ }^{19}$

Functionally, such divisions have been more long-standing, with specific arrangements and agencies in areas such as nuclear proliferation and transnational crime. The greatest change, however, involves the transformation of the division of labour between public and private actors which has markedly shifted towards a greater role for private actors. In the area of military security, this development has been most remarkable, since it has traditionally been viewed as the prerogative of governments. It was to safeguard governmental sovereignty in security that armaments industries were nationalized in Europe. With the trend to governance, this has changed. Many armaments companies have been privatized and transnational mergers have created increasingly large and internationally influential actors in the making of defence policy. In addition, governments and international organizations have begun to employ private security companies at home and abroad. In the areas of non-traditional security, the UN is cooperating with charities and NGOs in the delivery of humanitarian aid, and environmental agencies at the national and international level rely on local actors for the implementation of their regulations.

\section{Conclusion}

The preceding analysis has illustrated that the increasing complexity of the transatlantic security architecture may be explained by the emergence of a system of security governance. However, this article contends that the rise of security governance in Europe and North America should be understood not as an end point. It is rather an evolution which is progressing at different speeds or even different directions in each of the seven dimensions identified above. How this evolution will develop is a question which can only be speculated about. The theoretical framework proposed in this article helps to provide possible answers to this question in terms of the general trend from government to governance. Moreover, it suggests that we can draw on the comparison with the emergence of governance arrangements in areas such as local government, welfare and the environment 
to understand this evolution. Across these arenas, governance has been characterized by features and problems which might affect the emerging system of security governance in Europe and North America. These characteristics and problems are quite distinct from those addressed by balanceof-power theory, security regimes and security communities. Specifically, the analysis of security governance raises the questions of how the shift from government to governance affects our understanding of security and what consequences the fragmentation of power and authority has for the making and implementation of security policies in the region.

The first question has particular implications for the debate over the widening and deepening of the concept of security. It suggests that the argument that the nation-state and its defence should remain at the core of security studies because the state is the means by which societal and individual security is achieved (Ullman, 1983) might increasingly rest on a false premise. If, as this article has illustrated, security policies are made and implemented by a growing number of public and private actors at different levels of analysis, we might be required to reconsider the underlying assumptions of security studies.

The second question directs research to the political and practical issues which have been associated with the shift from government to governance in other sectors, such as lack of coordination and accountability. Coordination has emerged as a problem due to the functional and often geographical fragmentation of the networks on which governance is based. While government has been identified with the direct provision of a broad range of public services in diverse sectors and the ability to develop a unified policy approach across issue areas, governance faces inherent difficulties if policies need to be coordinated. Not only are specialized governmental and non-governmental actors dealing with the making and implementation of policies in each sector, but also the supervision of their services has often been delegated to independent agencies. Attempts by governments to retain control over different sectors are inhibited by the complexity of governance arrangements and the limits of regulatory policy. The problem of accountability in governance arrangements is closely associated with their fragmentation (Stewart and Stoker, 1995: 203; Rhodes, 1999: xxii). It has its roots in the dispersion of authority among multiple public and private actors at the national and international level. In these arrangements, blame cannot be put clearly on a single agent and as a consequence governance failure is not easily resolved.

Although this article has illustrated that the evolution towards security governance in Europe and North America is at an early stage, both problems are increasingly at the heart of the debate over the future transatlantic security architecture. The questions of effective coordination and the distribution of authority were almost immediately brought to the fore in the case of the international intervention in the former Yugoslavia. Divergent perspectives over whether the European Union, NATO or the UN should hold the authority over the international mission crucially delayed the response of the international community. Moreover, continuing disagreements over the responsibilities of the different organizations fostered incremental 
and sometimes conflicting policies during the course of the international intervention. Recently the issue of coordination has re-emerged over the creation of an independent European army as well as over the different processes of NATO and European Union enlargement.

The utility of the concept of security governance lies not only in directing the focus of security studies towards these theoretical and practical issues, but also in suggesting future research on the possible solutions by encouraging comparison with the development of governance in other issue areas.

\section{Notes}

1. For the increased emphasis placed on selective multilateral collaboration, see reports by European defence ministries, such as Denmark at http://www.fmn.dk/english/indhld.asp?cat_id=300 and the UK at http:// www.mod.uk/issues/cooperation.

2. Measures of de-governmentalization have been proposed elsewhere; see, for instance, Wolf (2001). However, a detailed assessment of the degree of degovernmentalization is beyond the scope of this article, which first seeks to demonstrate the relevance of the governance concept for the analysis of transatlantic security.

3. See Founding Act on Mutual Relations, Cooperation and Security between NATO and the Russian Federation, Paris, 27 May 1997, at http:// www.nato.int/docu/basictxt/fndact_a.htm; Charter on a Distinctive Partnership between the North Atlantic Treaty Organization and Ukraine, Madrid, 9 July 1997, at http://www.nato.int/docu/basictxt/ukrchrt.htm.

4. See, for instance, the British 'Outreach' programme, at http:// www.mod.uk/index.php3? page $=527$.

5. See, for instance, NATO Defence Planning Committee and Nuclear Planning Committee, Ministerial Communique, Brussels, 28-9 May 1991, at http://www.nato.int/docu/comm/comm91.htm.

6. North Atlantic Council, The Alliance's New Strategic Concept, Rome, 7-8 November 1991, at http://www.nato.int/docu/comm/49_95/c911107a.htm.

7. See OSCE, Human Dimension, at http://www.osce.org/docs/english/hde.htm; UN, Human Rights, at http://www.un.org/rights/ and UN, Humanitarian Affairs, at http://www.un.org/ha/.

8. See, for instance, the part-privatization of the Defence Evaluation and Research Agency (DERA) in July 2000 at http://www.dera.mod.uk/ html/whoweare/dera_and_ppp.htm; see also extracts from a speech by the Minister of State for the Armed Forces, John Spellar MP, to the PFI and Defence Conference, 14 March 2000, at http://www.mod.uk/index.php3?page=2077.

9. European Council, Santa Maria de Feira, 19-20 June 2000, at http://www.weu.int/eng/about.html.

10. Final Communiqué, North Atlantic Council, 4 June 1992, Oslo, at http://www.nato.int/docu/comm/49_95/c920604a.htm; Final Communiqué, Defence Planning Committee, 11 December 1992, Brussels, at http://www.nato.int/ docu/comm/49_95/c921211a.htm; Western European Union Council of Ministers, Petersberg Declaration, 19 June 1992, Bonn, at http://www.weu.int/eng/ documents.html. 
11. Message from Turnberry, North Atlantic Council, 7-8 June 1990, Turnberry, UK, at http://www.nato.int/docu/comm/49_95/c900608b.htm.

12. See 'Putin Urges End to Nato Expansion', New York Times, 9 February 2001; Anthony J. Blinken, 'NATO Needs to Grow', New York Times, 2 April 2001; 'Baltics' Place in NATO', New York Times, 11 April 2001; Jackson Diehl, 'NATO's Expansion Tool', Washington Post, 19 February 2001.

13. See Towards a Partnership for the 21st Century. The Enhanced and More Operational Partnership, Report by the Political Military Steering Committee on Partnership for Peace, at http://www.nato.int/pfp/docu/d990615g.htm.

14. See http://www.europa.eu.int/comm/external_relations/cfsp/intro/index.htm.

15. Editorial comments: 'NATO's Kosovo Intervention', American Journal of International Law 93: 4, 1999, at http://www.asil.org/kosovo.htm.

16. The consensus minus one rule was adopted by the CSCE in Prague and the consensus minus two rule in Stockholm in 1992, see CSCE, Summary of Conclusions, Prague, January 1992, at http://www.osce.org/docs/english/ 1990_1999/mcs/2prag92e.htm and CSCE, Summary of Conclusions, Stockholm, December 1992 at http://www.osce.org/docs/english/1990_1999/mcs/3stoc92e.htm.

17. During the Nice Summit the EU thus came under considerable pressure from Germany to increase its votes. However, although the summit fell short of a drastic reconsideration, smaller states such as Belgium and The Netherlands lost proportionally in influence and further changes are likely with the prospective European Union enlargement. See Ian Black, 'Failure Unthinkable for EU Leaders', Guardian, 2 December 2000; Roger Cohen, 'New Europe's Changing Landscape Strains French-German Ties', New York Times, 16 December 2000; Johan Huizinga, 'Nice Summit Produces Meagre Results', Radio Netherlands, at http://www.rnw.nl/ hotspots/html/eu001211.html.

18. CSCE, Summary of Conclusions, Prague, January 1992, at http://www.osce.org/docs/english/1990_1999/mcs/2prag92e.htm; CSCE, Summary of Conclusions, Stockholm, December 1992 at http://www.osce.org/docs/english/ 1990_1999/mcs/3stoc92e.htm.

19. See Michael R. Gordon, 'A Nation Challenged: Turkey; NATO Offers Peacekeeping Planning Aid', New York Times, 11 April 2002.

\section{References}

Adams, T. K. (1999) 'The New Mercenaries and the Privatization of Conflict', Parameters, Summer, pp. 103-16.

Adler, E. and Barnett, M. (1998) 'A Framework for the Study of Security Communities', in Emanuel Adler and Michael Barnett (eds) Security Communities, pp. 29-65. Cambridge: Cambridge University Press.

Amnesty International (2002) Amnesty International Report 2002. London: Amnesty International.

Aquina, H. and Bekke, H. (1993) 'Governance in Interaction: Public Tasks and Private Organisations', in Jon Koiman (ed.) Modern Governance: New Government-Society Interactions, pp. 159-70. London: Sage.

Arnold, G. (1999) Mercenaries: The Scourge of the Third World. Basingstoke: Macmillan.

Baldwin, D. A. (1997) 'The Concept of Security', Review of International Studies 23(1): 5-29.

Bensahel, N. (1999) 'Separable But Not Separate Forces: NATO's Development of the Combined Joint Task Force', European Security 8(2): 52-72. 
Bitzinger, R. A. (1994) 'The Globalization of the Arms Industry: The Next Proliferation Challenge', International Security 19(2): 170-98.

Brooks, D. (2000) 'Messiahs or Mercenaries? The Future of International Military Services', International Peacekeeping 7(4): 129-44.

Butcher, T. (1995) Delivering Welfare: The Governance of the Social Services in the 1990s. Buckingham: Open University Press.

Bøås, M. (2000) 'Security Communities: Whose Security?', Cooperation and Conflict 35(3): 309-19.

CARE (2001) CARE USA - Annual Report 2001, at: http://www.careusa.org/ newsroom/publications/annualreports/2001/index.asp.

Carver, M. (1992) Tightrope Walking: British Defence Policy since 1945. London: Random Century.

Clapp, J. (1998) 'The Privatization of Global Environmental Governance: ISO 14000 and the Developing World', Global Governance 4(3): 295-316.

Commission on Global Governance (1995) Our Global Neighbourhood: The Report of the Commission on Global Governance. Oxford: Oxford University Press.

Cooley, A. and Ron, J. (2002) 'The NGO Scramble: Organizational Insecurity and the Political Economy of Transnational Action', International Security 27(1): 5-39.

Cottey, A. (2000) 'Europe's New Subregionalism', Journal of Strategic Studies 23(2): 23-47.

Croft, S. and Dunn, D. H. (1990) 'The Impact of the Defence Budget on Arms Control Policy', in Mark Hoffmann (ed.) UK Arms Control Policy in the 1990s, pp. 53-69. Manchester: Manchester University Press.

CSCE (1992) Helsinki Document, at: http://www.osce.org/odihr/hdim2001/ index.php3?sc $=9$.

Czempiel, E.-O. (1992) 'Governance and Democratization', in James N. Rosenau and Ernst-Otto Czempiel (eds) Governance without Government: Order and Change in World Politics, pp. 250-71. Cambridge: Cambridge University Press.

Eising, R., and Kohler-Koch, B. (1999) 'Introduction: Network Governance in the European Union', in Rainer Eising and Beate Kohler Koch (eds) The Transformation of Governance in the European Union, pp. 3-13. London: Routledge.

Gordenker, L. and Weiss, T. G. (1996) 'Pluralizing Global Governance: Analytical Approaches and Dimensions', in Gordenker and Weiss (eds) NGOs, the UN, and Global Governance, pp. 17-47. London: Lynne Rienner.

Greenwood, D. (1991) 'Expenditure and Management', in Peter Byrd (ed.) British Defence Policy: Thatcher and Beyond, pp. 36-66. New York: Philip Allan.

Guay, T. R. (1998) At Arm's Length: the European Union and Europe's Defence Industry. Basingstoke: Macmillan.

Hueglin, T. O. (1999) 'Government, Governance, Governmentality', in Beate Kohler-Koch and Rainer Eising (eds) The Transformation of Governance in the European Union, pp. 245-65. London: Routledge.

Human Rights Watch (2002) World Report 2002. New York: Human Rights Watch.

Hurlburt, H. (1995) 'Russia, the OSCE and European Security Architecture', Helsinki Monitor 2 at http://www.ssn.ethz.ch/static/osce/h_monit/hel95_2/ hurlburt.htm.

ICRC (International Committee of the Red Cross) (2001) Annual Report 2001. Geneva: ICRC.

International Rescue Committee (2002) International Rescue Committee Annual Report 2001-2002. New York: International Rescue Committee.

Jervis, R. (1982) 'Security Regimes', International Organization 36(2): 356-78.

Jessop, B. (1999) 'The Changing Governance of Welfare: Recent Trends in its 
Primary Functions, Scale, and Modes of Coordination', Social Policy \& Administration 33(4): 348-59.

Jessop, B. (2000) 'Governance Failure', in Gerry Stoker (ed.) The New Politics of British Local Governance, pp. 11-32. Basingstoke: Macmillan.

Jordan, A. (1999) 'Editorial Introduction: The Construction of a Multilevel Environmental Governance System', Environment and Planning C: Government and Policy 17(1): 1-17.

Kassebaum, D. (2000) 'A Question of Facts - The Legal Use of Private Security Firms in Bosnia', Columbia Journal of Transnational Law 38(3): 581-602.

Krahmann, E. (forthcoming) 'National, Regional and Global Governance: One Phenomenon or Many?', Global Governance.

Krasner, S. D. (1983) 'Structural Causes and Regime Consequences: Regimes as Intervening Variables', in S. D. Krasner (ed.) International Regimes, pp. 1-21. Ithaca, NY: Cornell University Press.

Krause, K. and Williams, M. C., eds (1997) Critical Security Studies: Concepts and Cases. Minneapolis: University of Minnesota Press.

Kupchan, C. A. (1998) 'After Pax Americana: Benign Power, Regional Integration, and the Sources of Stable Multipolarity', International Security 23(3): 40-79.

Layne, C. (1993) 'The Unipolar Illusion: Why New Great Powers Will Arise', International Security 17(4): 5-51.

Lilly, D. (2000) The Privatization of Security and Peacebuilding. London: International Alert.

Majone, G. (1997) 'From the Positive to the Regulatory State: Causes and Consequences of Changes in the Mode of Governance', Journal of Public Policy 17(2): 139-67.

Mandel, R. (2002) Armies Without States: The Privatization of Security. Boulder, CO: Lynne Rienner.

Manners, I. (2002) European (Security) Union: From Existential Threat to Ontological Security, Working Paper, Copenhagen: COPRI, at: http:// www.copri.dk/publications/workingpapers.htm.

Mayntz, R. (1993) 'Governing Failures and the Problem of Governability: Some Comments on a Theoretical Paradigm', in Jan Koiman (ed.) Modern Governance: New Government-Society Interactions, pp. 9-20. London: Sage.

Mearsheimer, J. J. (1990a) 'Why We Will Soon Miss the Cold War', The Atlantic Monthly 266(2): 35-50.

Mearsheimer, J. J. (1990b) 'Back to the Future: Instability in Europe After the Cold War', International Security 15(2): 5-56.

Mittelman, J. H. (1996) 'Rethinking the "New Regionalism" in the Context of Globalization', Global Governance 2(2): 189-213.

MRPI (Military Professional Resources Limited) (2002), Overview, at: http://www.mpri.com/channels/int_overview.html.

NATO (2000) NATO Civil-Military Co-operation (CIMIC) Doctrine, AJP-09, at: http://63.104.169.22/PDF/AJP-09.pdf.

OXFAM (2000) Oxfam International Annual Report 2000. Oxford: Oxfam.

Pagoulatos, G. (1999) 'European Banking: Five Modes of Governance', West European Politics 22(1): 68-94.

Payne, A. (2000) 'Globalization and Modes of Regionalist Governance', in Jon Pierre (ed.) Debating Governance: Authority, Steering, and Democracy, pp. 202-18. Oxford: Oxford University Press.

Pierre, J. (2000a) 'Introduction: Understanding Governance', in Jon Pierre (ed.) Debating Governance: Authority, Steering, and Democracy, pp. 1-10. Oxford: Oxford University Press. 
Pierre, J. (2000b) 'Conclusion: Governance Beyond State Strength', in Jon Pierre (ed.) Debating Governance: Authority, Steering, and Democracy, pp. 242-6. Oxford: Oxford University Press.

Rhodes, R. A. W. (1996) 'The New Governance: Governing without Government', Political Studies XLIV: 652-67.

Rhodes, R. A. W. (1999) 'Foreword: Governance and Networks', in Gerry Stoker (ed.) The New Management of British Local Governance, pp. xii-xxvi. Basingstoke: Macmillan.

Rose, R. (1980) 'The Nature of the Challenge', in Richard Rose (ed.) Challenges to Governance: Studies in Overloaded Polities, pp. 5-28. Beverly Hills, CA: Sage.

Rosenau, J. N. (1992) 'Governance, Order and Change in World Politics', in James N. Rosenau and Ernst-Otto Czempiel (eds) Governance without Government: Order and Change in World Politics, pp. 1-29. Cambridge: Cambridge University Press.

Rosenau, J. N. (2000) 'Change, Complexity, and Governance in Globalizing Space', in Jon Pierre (ed.) Debating Governance: Authority, Steering, and Democracy, pp. 169-200. Oxford: Oxford University Press.

Rothschild, E. (1995) 'What is Security?', Daedalus 124(3): 53-98.

Self, P. (1980) 'Resource and Policy Co-ordination under Pressure', in Richard Rose (ed.) Challenges to Governance: Studies in Overloaded Polities, pp. 29-51. Beverly Hills, CA: Sage.

Senghaas, D. (1993) 'Global Governance: How Could It Be Conceived?', Security Dialogue 24(3): 247-56.

Sharp, J. M. O. (1995) 'Let's Make a Deal: NATO and CFE', Bulletin of the Atomic Scientists, March/April, at http://www.bullatomsci.org/issues/1995/ma95/ ma92.perspective.html.

Singer, P. W. (2001) 'Corporate Warriors: The Rise and Ramifications of the Privatized Military Industry', International Security 26(3); also at: http://www.brook.edu/dybdocroot/views/articles/singer/20020128.htm.

Sköns, E. and Wulf, H. (1994) 'The Internationalization of the Arms Industry', Annals of the American Academy of Political and Social Science 535: 43-57.

Smith, R. (1993) 'Resources, Commitments and the Defence Industry', in Michael Clarke and Philip Sabin (eds) British Defence Choices for the Twenty-First Century. London: Brassey's.

Snyder, C. (1996) 'Emerging Regional Security Co-operation in Europe and the Asia Pacific', Pacific Review 9(4): 553-76.

Spearin, C. (2001) 'Private Security Companies and Humanitarians: A Corporate Solution to Securing Humanitarian Spaces?', International Peacekeeping 8(1): 20-43.

Stewart, J. and Stoker, G. (1995) 'Fifteen Years of Local Government Restructuring 1974-94: An Evaluation', in J. Stewart and G. Stoker (eds) Local Government in the 1990s, pp. 191-209. Basingstoke: Macmillan.

Stoker, G. (2000) 'Introduction', in G. Stoker (ed.) The New Politics of British Local Governance. Basingstoke: Macmillan.

Treaty of the European Union (1997), Official Journal C340, 10.11.1997, pp. 145-72.

Tuathail, G. Ó., Herod, A. and Roberts, S. M. (1998) 'Negotiating Unruly Problematics', in Andrew Herod, Gearóid Ó Tuathail and Susan M. Roberts (eds) An Unruly World? Globalization, Governance and Geography, pp. 1-24. London: Routledge.

Ullman, R. H. (1983) 'Redefining Security’, International Security 8(1): 129-53.

UNAIDS (2000) Report on the global HIV/AIDS epidemic, at http://www. unaids.org/epidemic_update/report/glo_estim.pdf

UN Charter (1945) at http://www.un.org/aboutun/charter/. 
Walsh, K. (1995) 'Competition and Public Service Delivery', in John Stewart and Gerry Stoker (eds) Local Government in the 1990s, pp. 28-48. Basingstoke: Macmillan.

Walt, S. M. (1991) 'The Renaissance of Security Studies', International Studies Quarterly 35(2): 211-39.

Waltz, K. (1993) 'The Emerging Structure of International Politics', International Security 18(2): 44-79.

Wohlforth, W. C. (1999) 'The Stability of a Unipolar World', International Security 24(4): 5-41.

Wolf, K. D. (2001) 'Private Actors and the Legitimacy of Governance Beyond the State'. Paper presented at the ECPR workshop 'Governance and Democratic Legitimacy', Grenoble 6-11 April, at: http://www.essex.ac.uk/ecpr/jointsessions/ grenoble/papers/ws5/wolf/pdf.

Wæver, O. (1995) 'Securitization and Desecuritization', in Ronnie D. Lipschutz (ed.) On Security, pp. 46-86. New York: Columbia University Press.

Young, O. (ed.) (1997) Global Governance: Drawing Insights from the Environmental Experience. Cambridge, MA: MIT Press.

Zangl, B. and Zürn, M. (1999) 'The Effects of Denationalisation on Security in the OECD World', Global Society 13(2): 139-61.

ELKE KRAHMANN is currently a DAAD Visiting Fellow at the Center for European Studies at Harvard University. She is the author of Multilevel Networks in European Foreign Policy (Ashgate, 2003) and has published on post-cold war security and governance in journals such as International Affairs and Global Governance. Her new research project examines the growing role of private military companies in international security.

Address: Center for European Studies, Harvard University, 27 Kirkland Street, Cambridge, MA 02138, USA.

[email: krahmann@fas.harvard.edu] 